\title{
Sports dentistry: a perspective for the future
}

CDD. 20.ed. 617.1

617.6

796

http://dx.doi.org/10.1590/1807-55092014000200351

\author{
Paulo Vinícius SOARES \\ Andrea Barros TOLENTINO* \\ Alexandre Coelho MACHADO* \\ Reinaldo Brito DIAS** \\ Neide Pena COTO**
}

*Escola de Odontologia Universidade Federal de Uberlândia.

${ }^{* *}$ Departamento de Cirurgia, Prótese e Traumatologia maxilofacial, Universidade de São Paulo.

\begin{abstract}
Sports Dentistry (SD) acts in the prevention, maintenance and treatment of oral and facial injuries, as well as the collection and dissemination of information on dental trauma, beyond stimulus to research. Establishes as a duty for the dentist detect problems related to the athlete's stomatognathic system. This essay is based on the provided data from the literature related to SD, including definition, practice areas and research fields. To discuss the data, six areas were categorized: shares in sports dentistry; oral health of athlete; sports-related dental implications; dental-facial trauma; face shields; and mouthguards. The analyzed data show that the SD is still an underexplored field of action by dentists, but it is expanding, despite not being recognized specialty by the Federal Council of Dentistry, but the Brazilian Academy of Sports Dentistry has been created with a mission to show the real importance of Dentistry in sport. The dentist should be part of the group of professionals associated with the athlete to perform periodic checks in order to ensure oral health which may contribute to athletes'performance. When impact occurs, however, it would be possible reduce the severity of the impact related to injuries, by using helmets, masks, goggles, face shields and mouthguard. Additionally, it is imperative that dentists, sports coaching, athletes, and professional who work with athletes be aware of the benefits of incorporating SD as an important academic and professional subject.
\end{abstract}

KEY WORDS: Mouthguard; Face shield; Trauma; Athletes's oral health.

\section{Introduction}

In time where the words of Baron de Coubertin "The important thing in life is not the triumph but the struggle" to improve the athlete's performance was not as much meaning these days where the important thing is to win. Depending on the sport practiced, milliseconds can make the podium and the health of the athlete now has vital importance. For this there was a great incentive for research to bring improvement in athletic performance, talent detection, care that result in breaking records, medals and trophies. With the results of these surveys Clubs, Associations and Institutions started to give due consideration to performance of their athletes thus providing its professional staff involved in the day to day of these in physiology, biomechanics, game analyst, nutritionists, physiotherapists, psychologists, doctors and dentists currently.

The role of dentistry in the sports is important, because it provides the athlete optimal oral health conditions which in turn can contribute to achievement of optimal performance during competitions. Sports Dentistry (SD) involves the prevention, maintenance and treatment of oral and facial injuries, as well as the collection and dissemination of information on dental trauma, in addition to stimulating research ${ }^{1}$. It directs a duty of the dentist detect problems of the athlete, such as mouth breathing, poor positioning of the arches, and properly administer medications free of substances, that may provide the positive doping present in many painkillers. The SD is still recent in Brazil, and the Federal Council of Dentistry (FCD) does not recognize the SD as a specialty and it is not included as a compulsory subject in the curriculum offered at most universities.

Among the different sports, there are those which the risk of injury due to the contact or impact can 
be considered high. For instance, some team sports and combat sports such as. Sports as boxing, judo, karate, jiu-jitsu, wrestling, sumo, soccer, basketball, volleyball, handball, mountain biking, motocross, hockey and skating. As a result, not saving efforts with epidemiological studies about injuries in sports and the resulting establishment of preventive methods. It is estimated that approximately 150,000 injuries to the mouth tissues are prevented annually through mouthguards during the practice of sport ${ }^{2}$.

\section{Shares in sports dentistry}

The history of SD in Brazil happens concomitant with the occurrence of some of the major sporting events and refers to the time of the World Cup Soccer 1958, when the dentist Mario Trigo accompanied Brazillian soccer team during this competition and consequently in the Cups of 1962 and 1966. In 1958, in Sweden, Trigo performed 118 extractions on 33 players. As a dentist of Fluminense Football Club, Trigo reports had observed that athletes who waited longer to recover of concussions were precisely those who had dental infection. After elimination of the infection, athlete's recovery was faster, optimizing treatment and facilitating the team squad ${ }^{3}$.

Until 1990s, there were few dental professionals working in the sports field. Between 1992 and 1996, only 10 Brazilian soccer's teams, of a total of 42 , has dental offices in threes headquarters. Professional football institutions mostly lacked dentists working in conjunction with the coaching staff, using outsourced services, targeting more curative treatment in relation to preventive interventions $s^{4}$.

Aldo Forli Scocate was the dentist responsible for the oral health of Olympic athletes in 1992, performed 265 assistances. The average of 14.6 patients per day is high rate high for a delegation with just over 300 members. As a result of the treatment during the Olympics, there was an increase of psychological situation of athletes and the improved of muscle performance reacquired ${ }^{4}$.

The dental care at the Athens Olympics in 2004 was the second most searched service in the Olympics, behind only physiotherapy. The dental clinic was in the field of medical care area
Observing the need for expanding and disseminating knowledge about this field of dentistry, due to scarce studies about SD, the objective of this essay is define and discuss some published articles in this area, as well as the role of professionals, focused on the prevention methods and frequent risk situations that involve athletes. Six areas were categorized in this essay: shares in sport dentistry; oral health of athlete; sport-related dental implications; dento-facial trauma, face shields, and mouthguard.

of the Olympic Village, where 28 dentists treated 658 patients. The most common procedures were restorations (313 permanent and 31 temporary) and endodontic treatment. The second week of games was the period of greatest achievement of procedures 5 .

In Beijing Olympics in 2008, 80 dentists performed about 1600 treatments. As in the previous edition of the games, were held several restorations and endodontic treatment, with a large number of cases of pericoronitis treatment and mouthguards confection. When comparing the number of procedures crippling performed in Beijing Games with the 1968 Olympics, held in Mexico, there is a decrease in procedures such as tooth extraction, from 370 to 47 cases. This fact highlights the philosophy and acting of a minimal invasive dentistry, and more careful with the health of the athlete ${ }^{6}$.

The political interaction between unions, councils and associations, as well as discussions forums are relevant to cover the area of SD actuation. The first World Congress of Sports Dentistry and Dental Traumatology was held in Boston - USA, in June 2001. This meeting summarized the relationship between two international organizations: International Association of Dental Traumatology (IADT) and International Academy for Sports Dentistry (SDA), which decided to publish official journal Dental Traumatology ${ }^{7}$. Brazilian Dental Association (BDO) searchs for greater integration of the dentist in sports, and is the response of the bill PL 5391/2005, which defines how the presence of standard dentist specializing in SD at a competition ${ }^{8}$. 


\section{Oral health of athlete}

The high standards of performance required of athletes can only be achieved by an individual totally healthy. The time, effort and money invested in realization of this maximum level of fitness should not be jeopardized by preventable oral health problems, which occur before or during competition?

To provide the best performance, it is important that the dentist make a detailed assessment of oral health status of the athlete to detect changes and pathologies such as dental malocclusion. If the athlete presents alterations in the occlusion can be significantly compromising the performance since it interferes with the efficacy of chewing, and subsequent digestion of food, thus impairing nutrient absorption. The loss of muscle balance, headache, temporomandibular joint problems, discomfort and stress can also be an imbalance occlusal ${ }^{10}$.

From 2003 to 2006, professional players of the Spanish football team Barcelona Football Club were compared with students of Dentistry and Medicine, University of Barcelona. The average active caries was significantly higher among professional football, adopting as justification that students are more sensitive / willing to dental treatment ${ }^{11}$. Agreeing with the increased risk of dental caries among soccer players, when approached female cast, $57 \%$ had the disease, demonstrating the importance of establishing a program of oral health from the health promotion related to the sport practice ${ }^{12-13}$.

The oral health problem affects not only professional athletes, worsening among amateur athletes, as shown in a study that evaluated nearly 400 records of football players, with 353 amateurs and 47 professionals. The results showed that amateur athletes are more alarming: 283 caries lesions $-71 \%$, root canal 109 - 27\% 33 abscesses - 9\% extractions and $78-22 \%$ when compared to professional athletes: 32 cases of cavities - $68 \%$, root canal $11-23 \%$, no cases of abscess $-0 \%$ and 24 extractions $-51 \%{ }^{14}$.

Therefore, it's duty of the dentist active in SD conduct regular reviews to identify any changes and diseases and to promote health education. The duty of dentist is working with patients, identifying individual risks, whether physiological or modality, and develop prevention plans that are enjoyable to the feeding requirements of the athlete and lifestyle ${ }^{15}$.

\section{Sports-related dental implications}

Sports drinks, especially carbonated are often consumed by the population, mainly by professional athletes and amateur sports people, with the purpose of rehydration and electrolyte replacement during highly aerobic sports ${ }^{16}$. These drinks have detrimental effect on the teeth due to the low $\mathrm{pH}$ and the presence of citric acid in its composition, which can be potentially erosive for tooth tissue if consumed improperly and with high frequency ${ }^{17}$.

When the $\mathrm{pH}$ reached 5.5, the hydroxyapatite crystals begin to dissolve, so below this value the enamel is at risk of decalcification ${ }^{18}$. Another negative effect of the low $\mathrm{pH}$ of carbonated sports drinks is the potential of being harmful to the properties of the composites. An in vitro study concluded that energy drinks used affected the color of composite resin restorations evaluated after a period of six months ${ }^{11}$.

Swimming athletes are affected with biocorrosion enamel because the pools are chlorinated to reduce bacterial contamination and algae. Although a low $\mathrm{pH}$ can cause irritation in the absence of appropriate glasses, excess chlorine in the water. It can not be detected by swimmers, allowing the acidic water in contact with the teeth, could cause irreversible tooth structure wear ${ }^{20}$. In published case, swimming athlete showed several loss of tooth enamel, in just two weeks, especially in their anterior teeth. This case emphasizes the need to ensure that the water is properly chlorinated and $\mathrm{pH}$ adjusted to $7.5^{21}$.

Also in relation to water sports, divers can suffer barodontalgia, considered an intraoral pain evoked by changes in barometric pressure. Changing the volume of gas within cavities of the rigid body, associated with fluctuations in atmospheric pressure can cause adverse effects, being the most common oral diseases reported as possible sources of barodontalgia: unsatisfactory dental restorations $(30.31 \%)$, dental caries without pulp involvement (29.2\%), inflammation of the pulp / periradicular necrotic (27.8\%), vital pulp pathology $(13.9 \%)$ and recent dental treatment (barodontalgia postoperatively, $11.1 \%)^{22-23}$.

Already dental barotrauma, can manifest as tooth fracture reduction and retention of dental restoration or fracture, caused by changes in atmospheric 
pressure. Besides the need for dental treatment, the potential consequences include aspiration or swallowing of the fragment of restoration and / or pain, which can lead to incapacitation or disruption during the dive ${ }^{24}$. Therefore, when acting

\section{Dental-facial trauma}

Worldwide, there is a rise in the number of practitioners of regular vigorous physical activity and contact sports. Unfortunately, the benefits provided by physical activity are associated with the risk of injury, including hard and soft tissue trauma ${ }^{26}$. Contact sport athletes have up to $10 \%$ more probability of suffering orofacial injury when compared to non-practitioners ${ }^{26}$ and $33-56 \%$ risk of suffering a facial injury during his career ${ }^{2}$.

Regarding to hard tissue trauma, nasal bone is one of the most affected structures in sports accidents, because it is located in a vulnerable area of the face and projected forward in relation to adjacent structures ${ }^{27}$. In cyclists, the zygomatic bone is the most prevalent fracture $(30.8 \%)$ and fractures of the temporomandibular joint with a rate of $18.8 \%$. It is essential to adopt preventive methods for high impact sports, to minimize traumas that can jeopardize the career of an athlete ${ }^{28}$.

The dental trauma is the most common in sports activities and it is often associated with serious consequences: aesthetic, functional, economic and psychological. It will depend on severity, and it can even exclude the athlete of an important competition. These lesions are more occurrent in sports, such as mountain biking, roller, skate and

\section{Face shields}

Differently from traumas caused in the daily, if the event occurs during in the sports practice, it differs due to the possibility of prevention and softening of damages. It is possible through the education and the use of protective equipment, such as helmets and face shields and mouth (FS and MG) ${ }^{37}$.

The use of protective helmets is relevant in high-risk sports activities because it reduces the risk of oral, facial and skull lesions. The outer layer of modern helmets are usually fabricated from polycarbonate or polymers of higher quality, which promote better distribution of the stresses and for patients who dive, the dentist should perform periodic checks and preventive measures, including periapical and vitality test, with special attention to apical pathology, defective restorations and secondary caries lesions ${ }^{25}$.

aggressive contact sports. Amateur athletes have greater chance of injury than professional athletes ${ }^{29}$.

The front teeth are the most affected by dental trauma and the upper incisors are more predisposed to injury (52-90\%), due to the anatomical location ${ }^{30}$. The uncomplicated crown fractures are the most common (44 to $62.5 \%)^{30}$. In the 2007 Pan American Games, $39.8 \%$ of the injuries were fractures of enamel, and $21.9 \%$ of these were in daily practice or competition in their respective sports ${ }^{31}$. When considering each sport separately, $41.2 \%$ of the athletes in jiu-jitsu suffered dental trauma, $37.1 \%$ in team handball, $36.4 \%$ in basketball, football $23.2 \%$, $22.3 \%$ in judo and $11.5 \%$ in hockey 32 . In the event of avulsion, exists in the USA and EUROPE "Rescue Dental" kit, which improves periodontal healing with immediate replantation ${ }^{33-34}$.

Although $18.11 \%$ of athletes seek care after trauma, in Brazil the dentist is not widely inserted in sports activities ${ }^{35}$, providing that they rarely gets the first aid. When lesion occurs, it is recommended fast and appropriate attendance, because will help player to prevent or minimize psychological and/ or physiologic damage, beyond consequences that may occur as a result of trauma ${ }^{36}$.

forces attenuating impact energy ${ }^{38-39}$. The correct use of the helmet can protect against head injuries among riders snowboard when subjected to falls or collisions. However, there are a lot of practitioners who do not use the equipment, with $52.9 \%$ of the riders who have suffered dental or oral and facial trauma, reported not wearing a helmet ${ }^{40}$.

The location of the nasal bone is anatomically potentially more vulnerable and to protect this region, it is important which the material used for manufacture the nose shield has the adequate capacity of shock absorption, such as ethylene vinyl 
acetate (EVA). The shield made with a $2 \mathrm{~mm}$ layer of EVA superimposed by a flexible sheet of $1 \mathrm{~mm}$ EVA disk, the risk of fracture of the nose was reduced by decreasing the stresses in the bone after impact ${ }^{27}$.

Protective masks are used after facial fractures, usually individualized and used to protect and prevent recurrent injuries during the healing period. This shield promotes the dissipation of stresses resulting from the impact to the surrounding tissues and support structures ${ }^{41}$.

Eye injuries related to sports can be preventable in up to $90 \%$ of accidents, and the use of protective eyewear is responsible for preservation. This category should be effective shield for safety, but without compromising the viewing area of the sportsman. The

\section{Mouthguard}

Many of dento alveolar trauma resulting from sports activity could be minimized by the use of appropriate mouthguards, recommended by the American Dental Association (ADA) in sports since $1950^{44}$. This category is effective, in the case of an absorbing device inserted into the mouth to prevent and reduce potential dental trauma and adjacent structures, which may cause dental and maxillofacial injuries of moderate to severe. The use of MG is increasing and diffusing among athletes, becoming mandatory in certain sports: rugby, american football and ice hockey; and significantly reduces the incidence of dental injuries in these sports ${ }^{45}$.

Despite benefits, there is a lack of awareness among athletes to use the protectors during training and competitions. This fact is justified due to promote discomfort, breathing and pronunciation difficulties, besides the possible drop in athletic performance $^{10,44,46}$, still contested ${ }^{47}$.

Mouthguards are generally classified into three categories: pre-fabricated, thermoplastic and custom. Athletes tend to opt for prefabricated or thermoplastic because they find it less expensive. However, these categories have deficiencies such as excessive weight and unfitness. MG must be individually made by a dentist, using plaster model of the athlete, as determined by ASTM 697-8048 which also determines that MG for sports should
American Academy of Ophthalmology recommend the use of this equipment in sports activities with potential risk of injury to the eyes, however, this is not required in most sports. Although, it is few used by football players, this sport is becoming the leading cause of eye injury in the context of sports ${ }^{42-43}$.

Despite the wide availability of face shields, there is no guarantee that the entire oral and facial lesions will be prevented. However, the risk will be minimized because the damage depends on the magnitude and source of force, beyond the anatomical region reached ${ }^{41}$. Concomitant the use of face shields, an information program emphasizing importance of using protective clothing and education of urgency is essential and should be training routine ${ }^{40}$.

not hamper the phonetic and breathing, not affect the physical performance of the athlete and enable longer use the same equipment ${ }^{44,48-49}$.

The MG does not affect systemic functions of the athlete ${ }^{44}$, and acts better dissipating the stresses transmitted in the area of impact and reducing the incidence of: lacerations of soft tissue, trauma to the anterior teeth after a frontal blow, damage to the posterior teeth in both arches and mandibular fractures ${ }^{44,50}$. There are differences between researches on the use of MG related to the prevention of mild traumatic brain injury (MTBI). Controlled studies of neurological tried to demonstrate the effectiveness of MG to prevent this type of injury, and concluded that there was no changes in the result of preventing $\mathrm{MTBI}^{51}$.

In a study with about 150 students from dental schools and physical education, showed that $68 \%$ did not know any of the categories of MG on the market, with undergraduate courses provided the ones who least access to such knowledge ${ }^{52}$. A special education program emphasizing the importance of using mouthguards, as first aid measures for dental trauma. It is essential to promote the knowledge, awareness and motivation among athletes and coaches ${ }^{49}$. Future research is needed for better guidelines to increase its development and utility of the MG. In addition, a greater effort must be made effective strategies to promote health, increasing use of the equipment ${ }^{44}$. 


\section{Final considerations}

As stated above, dentistry has an important role in the athlete's health and consequently on sport performance. The presence of Dentist in athlete support staff is of paramount importance. Surveys have shown that systemic diseases can often be caused by a dental problem.

Actions to raise awareness of the importance of oral health in athletes as well as the need to use shields, which also minimizes maxillofacial injuries provide a brief return to sports activities in case of fractures are needed.

In some countries groups of research in this area already consolidated. Searches that determine material, geometry and ideal thickness of oral and facial protectors are underway with satisfactory results and that already have clinical applicability and reproducibility with proven effectiveness.

Studies that attest to the interference of oral health on overall health of the athlete must be considered because there is already news of athletes who died from bacterial endocarditis from foci of oral infections. Materials with different damping, odorless, biocompatible and incipient capacity should also be the focus of future research. Anyway dentistry must have their place of importance in the life of the athlete and the dentist should be one of the professionals involved in your day to day.

\section{References}

1. Academy for Sports Dentistry. Definition of sports dentistry. [cited 2013 Jan 13]. Available from: http://www.acadsportsdent.org.

2. National Youth Sports Safety Foundation, Inc; 2005. [cited 2012 nov 23]. Available from: "http://www.sportsdentistry. com/facts.html”.

3. Trigo M. The eternal soccer. Brasília: Thesaurus; 2002.

4. Costa SS. Odontologia desportiva na luta pelo reconhecimento. Rev Odontol UNICID. 2009;21:162-8.

5. Vougiouklakis G, Tzoutzas J, Farmakis E-T, Farmakis E-E, Antoniadou M, Mitsea A. Dental data of the Athens 2004 Olympic and Paralympic Games. Int J Sports Med. 2008;29:927-33.

6. Yang X-J, Schamach P, Dai J-P, et al. Dental service in 2008 Summer Olympic Games. Br J Sports Med. 2011;45:270-4.

7. Ranalli DN. Sports dentistry and dental traumatology. Dent Traumatol. 2002;18:231-6.

8. ABO - MG. Associação Brasileira de Odontologia. Odontologia desportiva conquista reconhecimento de atletas e profissionais. Correio ABO-MG. 2006;23:12-4.

9. Soler Badia D, Batchelor PA, Sheiham A. The prevalence of oral health problems in participants of the 1992 Olympic Games in Barcelona. Int Dent J. 1994;44:44-8.

10. Souza LA, Elmadjian TR, Dias RB, Coto NP. Prevalence of malocclusions in the13-20-year-old categories of football Athletes. Braz Oral Res. 2011;25:19-22.

11. Gay-Escoda C, Duarte-Pereira DMV, Ardèvol J, Pruna R, Fernandez J, Valmaseda-Castellón E. Study of the effect of oral health on physical condition of professional soccer players of the Football Club Barcelona. Med Oral Patol Oral Cir Bucal. 2011;16:436-9.

12. Sant'Anna GR, Simionato MRL, Suzuki MES. Sports dentistry: buccal and salivary profile of a female soccer team. Quintessence Int. 2004;35:649-52.

13. Ranalli DN, Elderkin DL. Oral health issues for adolescent athletes. Dent Clin North Am. 2006;50:119-37.

14. Rosa AF, Costa SB, Silva PRS, et al. Estudo descritivo de alteraçóes odontológicas verificadas em 400 jogadores de futebol. Rev Bras Med Esporte. 1999;5:55-8.

15. Bryant S, McLaughlin K, Morgaine K, Drummond B. Elite athletes and oral health. Int J Sports Med. 2011;32:720-4.

16. Mathew T, Casamassimo PS, Hayes JR. Relationship between sports drinks and dental erosion in 304 University Athletes in Columbus, Ohio, USA. Caries Res. 2002;36:281-7.

17. Sobral MAP, Luz MAAC, Teixeira AG, Garone Netto N. Influência da dieta líquida ácida no desenvolvimento de erosão dental. Pesqui Odontol Bras. 2000;14:406-10.

18. Milosevic A. Sports drinks hazard to teeth. BrJ Sports Med. 1997;31:28-30.

19. Erdemir U, Yildız E, Eren MM. Effects of sports drinks on colour stability of nanofilled and microhybrid composites after long-term immersion. J Dent. 2012;40:e55-63. 
20. Jahangiri L, Pigliacelli S, Kerr AR. Severe and rapid erosion of dental enamel from swimming: a clinical report. J Prosthet Dent. 2011;106:219-23.

21. Dawes C, Boroditsky CL. Rapid and severe tooth erosion from swimming in an improperly chlorinated pool: case report. J Can Dent Assoc. 2008;74:359-61.

22. Zadik Y. Barodontalgia. J Endod. 2009;35:481-5.

23. Zadik Y, Chapnick L, Goldstein L. In-flight barodontalgia: analysis of 29 cases in military aircrew. Aviat Space Environ Med. 2007;78:593-6.

24. Peker I, Erten H, Kayaoglu G. Dental restoration dislodgment and fracture during scuba diving: a case of barotrauma. J Am Dent Assoc. 2009;140:1118-21.

25. Zadik Y, Drucker S. Diving dentistry: a review of the dental implications of scuba diving. Aust Dent J. 2011;56:265-71.

26. Gardiner DM, Ranalli DN. Attitudinal factors influencing mouthguard utilization. Dent Clin North Am. 2000;44:53-65.

27. Coto NP, Meira JBC, Dias RB, Driemeier L, Roveri GO, Noritomi PY. Assessment of nose protector for sport activities: finite element analysis. Dent Traumatol. 2012;28:108-13.

28. Gassner R, Tuli T, Emshoff R, Waldhart E. Mountainbiking - a dangerous sport: comparison with bicycling on oral and maxillofacial trauma. Int J Oral Maxillofac Surg. 1999;28:188-91.

29. Glendor U. Aetiology and risk factors related to traumatic dental injuries: a review of the literature. Dent Traumatol. 2009;25:19-31.

30. Muller KE, Persic R, Pohl Y, Krastl G, Filippi A. Dental injuries in mountain biking: a survey in Switzerland, Austria, Germany and Italy. Dent Traumatol. 2008;24:522-7.

31. Andrade RA, Evans PLS, Almeida ALS, et al. Prevalence of dental trauma in Pan American Games athletes. Dent Traumatol. 2010;26:248-53.

32. Ferrari CH, Medeiros JMF. Dental and level of information: mouthguard use in different contact sports. Dental Traumatol. 2002;18:144-7.

33. Pohl Y, Filippi A, Kirschner H. Results after replantation of avulsed permanent teeth. II. Periodontal healing and the role of physiologic storage and antiresorptive-regenerative therapy (ART). Dent Traumatol. 2005;21:93-101.

34. Fasciglione D, Persic R, Pohl Y, Filippi A. Dental injuries in inline skating: level of information and prevention. Dent Traumatol. 2007;23:143-8.

35. D’Annibale AS. Levantamento de lesōes em atletas bucomaxilofacial de São Caetano do Sul. Rev Assoc Paul Cir Dent. 2004:467-72.

36. Frontera RR, Zanin L, Ambrosano GMB, Flório FM. Orofacial trauma in Brazilian basketball players and level of information concerning trauma and mouthguards. Dent Traumatol. 2011;27:208-16.

37. Caglar E, Kargul B, Tanboga I. Dental trauma and mouthguard usage among ice hockey players in Turkey premier league. Dent Traumatol. 2005;21:29-31.

38. Vetter L, Vanderby R, Broutman LJ. Influence of materials and structure on performance of a football helmet. Polym Eng Sci. 1987;27:406-21.

39. Glauser TA. Integrating clinical trial data into clinical practice. Neurology. 2002;58:S6-12.

40. Caglar E, Kuscu OO, Caliskan S, Sandalli N. Orofacial and dental injuries of snowboarders in Turkey. Dent Traumatol. 2010;26:164-7.

41. Farrington T, Onambele-Pearson G, Taylor RL, Earl P, Winwood K. A review of facial protective equipment use in sport and the impact on injury incidence. Br J Oral Maxillofac Surg. 2012;50:233-8.

42. American Academy of Pediatrics. Committee on Sports Medicine and Fitness. American Academy of Ophthalmology, Eye Health and Public Information Task Force. Protective eyewear for young athletes. Ophthalmology. 2004;111:600-3.

43. Capão Filipe JA. Soccer (football) ocular injuries: an important eye health problem. Br J Ophthalmol. 2004;88:159-60.

44. Duarte-Pereira DM, Del Rey-Santamaria M, Javierre-Garcés C, et al. Wearability and physiological effects of customfitted vs self-adapted mouthguards. Dent Traumatol. 2008;24:439-42.

45. Gebauer DP, Williamson RA, Wallman KE, Dawson BT. The effect of mouthguard design on respiratory function in athletes. Clin J Sport Med. 2011;21:95-100.

46. Duddy FA, Weissman J, Lee Sr RA, Paranjpe A, Johnson JD, Cohenca N. Influence of different types of mouthguards on strength and performance of collegiate athletes: a controlled-randomized trial. Dent Traumatol. 2012;28:263-7.

47. Brionnet JM, Roger-Leroi V, Tubert-Jeannin S, Garson A. Rugby players' satisfaction with custom-fitted mouthguards made with different materials. Community Dent Oral Epidemiol. 2001;29:234-8.

48. American Standards of Testing of Materials. ASTM F697-80 Standard practice for care and use of mouthguards. In: Annual Book of ASTM Standards. Philadelphia: ASTM; 1981. 
49. Boffano P, Boffano M, Gallesio C, Roccia F, Cignetti R, Piana R. Rugby athletes' awareness and compliance in the use of mouthguards in the North West of Italy. Dent Traumatol. 2012;28:210-3.

50. Westerman B, Stringfellow PM, Eccleston JA. EVA mouthguards: how thick should they be? Dent Traumatol. 2002;18:24-7.

51. Mihalik JP, McCaffrey MA, Rivera EM, et al. Effectiveness of mouthguards in reducing neurocognitive deficits following sports-related cerebral concussion. Dent Traumatol. 2007;23:14-20.

52. Sizo SR; Silva ES; Rocha MPC; Klautau EB. Avaliação do conhecimento em odontologia e educação física acerca dos protetores bucais. Rev Bras Med Esporte. 2009;15:282-6.

\begin{tabular}{|c|c|}
\hline $\begin{array}{r}\text { ENDEREÇo } \\
\text { Neide Pena Coto } \\
\text { Departamento de Cirurgia, Prótese e Traumatologia maxilo-facial } \\
\text { Universidade de São Paulo } \\
\text { Av. Lineu Prestes, 2227 } \\
\text { 05580-ooo - Sao Paulo - SP - BRASIL } \\
\text { e-mail: npcoto@usp.br }\end{array}$ & $\begin{array}{l}\text { Recebido para publicação: 22/04/2014 } \\
\text { Aceito: 05/05/2014 }\end{array}$ \\
\hline
\end{tabular}

358 • Rev Bras Educ Fís Esporte, (São Paulo) 2014 Abr-Jun; 28(2):351-58 